\title{
Transitions between community complexes: a case study analysing gradients through mountain ridges in South Hungary
}

\author{
LÁSZló ERDŐs*, MÁRTA ZALATNAI, ZOLTÁN BÁTORI, LÁSZló KÖRMÖCZI \\ Department of Ecology, University of Szeged, Közép fasor 52, H-6726 Szeged, Hungary
}

\begin{abstract}
The study of boundaries is a recurring theme in ecology. However, boundaries have been examined mainly on fine scales (between communities) and on coarse scales (between biomes), while boundaries of intermediate scales (e.g. between community complexes) are quite neglected. In this study, we analysed boundaries between mesic and xeric community complexes in a sub-Mediterranean karst area of South Hungary. We applied the moving split window (MSW) technique for boundary analysis. First, since the behaviour of MSW concerning complex vegetation patterns is not fully understood, we prepared artificial datasets (simulated communities) to test its capacities. Second, we established north-south oriented belt transects across mountain ridges of the Villány Mts, and investigated the transition between the community complexes of differently exposed slopes. Using MSW, we were able clearly to distinguish between transitional zones and zones that do not represent real transitions: peaks in the Z-score profile of MSW merge only in the case of transitional zones. Moreover, we found that peaks merge depending on the independence (distinctness) of the transitional zone: when it is distinct, peaks merge only at the largest window widths. In the Villány Mts, transitions seem to occur mostly in the grasslands north of the ridges. We demonstrated that these grasslands can be regarded as boundaries between mesic and xeric complexes or as zones in their own right, with their own two boundaries. Interpretation depends upon the scale of observation.
\end{abstract}

Keywords: MSW, edge, simulation, gradient, transition

Abbreviations: MSW - Moving split window, SED - Squared Euclidean distance

\section{Introduction}

The study of ecological gradients and boundaries has been in the focus of research efforts for decades (cf. WHITTAKER 1967, AUSTIN 2005). Boundaries are of particular importance, since they separate and connect neighbouring ecological units along a gradient

* Corresponding author, e-mail: erdos.laszlo@bio.u-szeged.hu

Copyright $^{\circledR} 2014$ by Acta Botanica Croatica, the Faculty of Science, University of Zagreb. All rights reserved. 
(ERDŐs et al. 2011b) and they control the flow of organisms, materials, energy, and information (WIENS et al. 1985, WIENS 1992, CADENASSO et al. 2003).

Ecological boundaries exist over a wide variety of spatial scales and organization levels (e.g. JAGOMÄGI et al. 1988, Gosz 1993, PETERS et al. 2006). Unfortunately, while boundaries on some scales have been intensively scrutinized, other scales are almost entirely neglected: most studies focus on boundaries between communities (fine-scale) or those between biomes (coarse scale) (KENT et al. 1997, PETERS et al. 2006). However, boundaries and transitional phenomena between vegetation complexes (intermediate scale) may also be important from an ecological perspective (cf. WESTHOFF 1974, vAN DER MAAREL 1976). Community complexes (also mentioned as phytocoenose complexes) are either mosaics of two or more communities (e.g. forest patches embedded in a grassland matrix) or series of different communities in one spatial direction (e.g. along decreasing moisture). In the case of ecological boundaries, the study of intermediate scales is especially important: knowledge on transitions between community complexes may contribute to the understanding of boundaries of lower and higher scales (KolASA and ZALEWSKI 1995, KenT et al. 1997, LAURANCE et al. 2001).

It is widely known that vegetation features differ considerably in north-facing and south-facing slopes (e.g. Armesto and Martínez 1978, Szabó 1990, Kutiel and LaveE 1999, Sternberg and Shoshany 2001, BÁtori et al. 2011, ERdös et al. 2012). However, differences are pronounced under some climatic conditions, but they are negligible in others. For example, humid Atlantic conditions in western Europe favour the existence of closed forests on both north-facing and south-facing slopes (JAKUCS 1972), while all slopes tend to be mostly treeless in arid and extreme-arid environments (KUTIEL and LAVEE 1999). In contrast, under Mediterranean and Continental (as well as sub-Mediterranean and sub-Continental) conditions, trees are much more abundant on north-facing than on south-facing slopes, resulting in great structural and compositional differences between the community complexes of the different slopes (cf. JAKUCS 1972, KUTIEL and LAVEE 1999, STERNBERG and SHOSHANY 2001).

It can be hypothesized that transition occurs somewhere near the ridge. However, knowledge on spatial processes and boundary properties across mountain ridges is limited. The few studies that focus on transitions occurring on mountain ridges use classical coenological methods with a limited capacity to characterize boundaries and transitional phenomena (e.g. KEVEY and BoRHIDI 1998, 2002, 2005).

Several methods have been developed to study ecological boundaries (HUFKENS et al. 2009). Moving split window (MSW) analysis is considered one of the best methods (KENT et al. 1997, also see Ludwig and CoRnelius 1987, CHOESIN and BoERnER 2002), and has been widely used in ecology (e.g. Muños-Reinoso 2001, ZALATNAI and KÖRMÖCZi 2004, Hennenberg et al. 2005, KRÖGER et al. 2009, TormA and KÖRMÖCZI 2009, ERDÖs et al. 2011a). MSW compares neighbouring areas of a transect using a dissimilarity function. Comparison is performed in a window consisting in the simplest case of two adjacent plots. Window width can be increased, so comparison can be made at several spatial resolutions. Although there have been some studies analysing the behaviour of the MSW method under different boundary conditions, using different window widths (BRUNT and CONLEY 1990, KÖRMÖCZI 2005), MSW behaviour with respect to more complex vegetation patterns is little understood. Moreover, promising as the method may seem at intermediate scales, it has not been used to study boundaries between community complexes. 
In this study, we used the MSW technique to examine boundary zones between community complexes of differently exposed slopes in a sub-Mediterranean karst area of Hungary. The strongly deviating vegetation types in the north-facing and the south facing slopes of the Villány Mts provided an excellent opportunity for the analysis of transitions between community complexes. First, we applied simulated communities to test the properties of the MSW method. Second, we analysed our field data gathered along north-south facing belt transects running through the mountain ridges. Our main goal was to provide a case study on boundary characteristics between community complexes, but we also aimed to contribute to knowledge on the behaviour of the MSW method under different boundary situations.

\section{Materials and methods}

\section{Study site}

Our study was conducted in the Villány Mountains (Hungary) (Fig. 1). The bedrock consists mainly of limestone, to a lesser degree of dolomite (LovÁsz 1977). Mean annual temperature is $10.5^{\circ} \mathrm{C}$ (FoDOR 1977), mean annual precipitation is $680 \mathrm{~mm}$ (AMBRózY and Kozma 1990). The area is situated in the temperate forest belt, but it is very close to the forest steppe zone (Pócs 2000, MAGYARI et al. 2010). Therefore, a complex of small shrubforest patches embedded in a dry grassland matrix occupies the warm and dry southern slopes (SIMON 1964, DÉNES 1995), whereas the cooler and moister northern slopes are covered mostly by mesic forests (HoRvÁt 1968) (Fig. 2). Near the ridges, on the northern slopes, a transitional grassland community has formed, with both mesic and xeric plant species (ERDŐs et al. 2010).

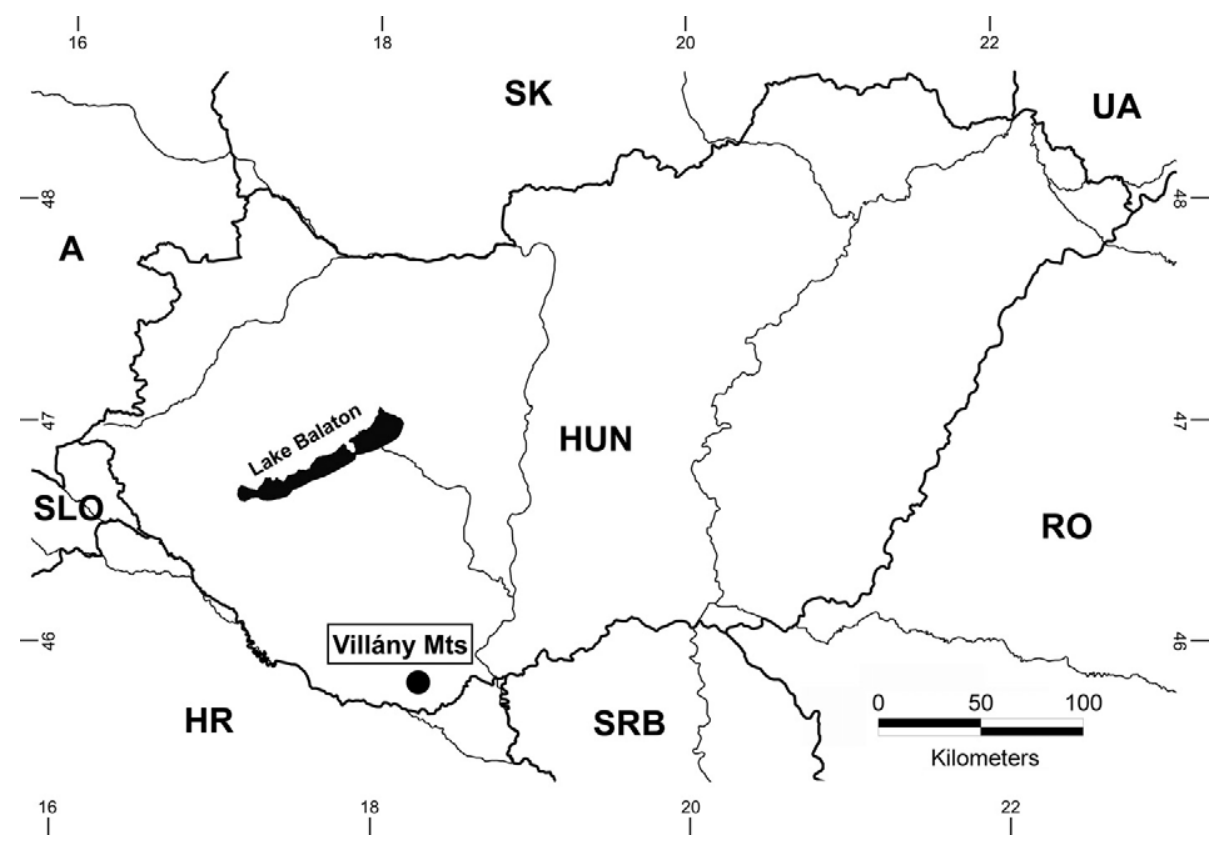

Fig. 1. Location of the study site in southern Hungary. 

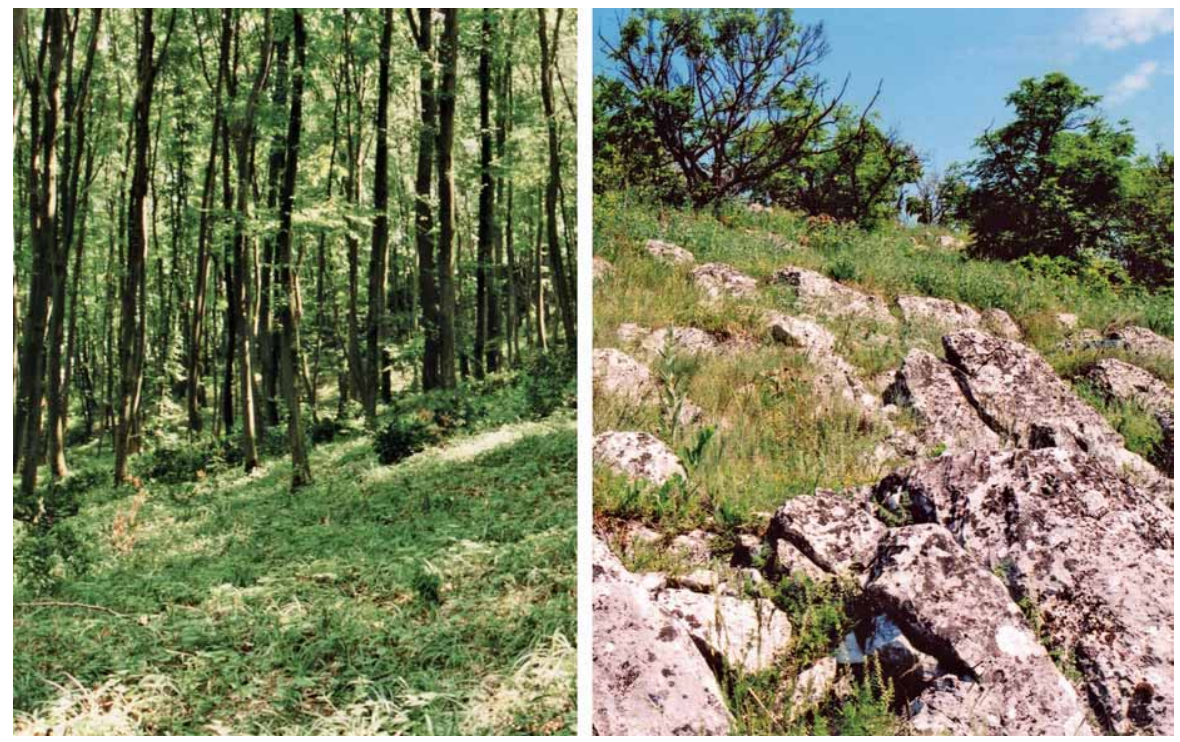

Fig. 2. Typical vegetation of the Villány Mts. On the left, a mesic forest of the northern slope can be seen. On the right, there is part of the xeric shrubforest-grassland complex.

For the present study, the three most intact areas of the Villány Mountains were chosen, where vegetation can be considered natural: Mt Szársomlyó, Mt Fekete and Mt Tenkes. Mt Szársomlyó and Mt Fekete are strictly protected nature reserves, whereas Mt Tenkes is being slated for legal protection. All of them have very high species richness (with a lot of relict and endemic species) and great habitat diversity (DÉNES 2000).

\section{Field studies}

Five north-south facing belt transects were established perpendicular to the mountain ridges (3 transects on Mt Szársomlyó: S1-S3, one transect on Mt Fekete: F, and one transect on Mt Tenkes: T). All transects were $200 \mathrm{~m}$ long, consisting of $1 \mathrm{~m}^{2}$ contiguous permanent quadrats. During field works in the period 2006-2010, the presence of all vascular plant species of the field layer was recorded twice (in April and in July). Spring and summer records were combined for each quadrat before the analyses.

\section{Artificial datasets}

Since performance of the MSW method on multiscale complex patterns is not sufficiently known, first we wanted to test how this technique performs on artificial data with known properties. Artificial datasets were prepared so as to resemble the real field situations in the Villány Mts. Five datasets were used, representing five possible species distribution patterns. Each set consists of 200 plots and either 150, or 120 or 90 species (Fig. 3). Species number depends on the structure of the artificial gradient. Species distributions near the boundaries were generated randomly so that probability of species occurrence decreased gradually away from the patch centre. Central patch or transition zone (in the middle of the gradient) is $20 \mathrm{~m}$ wide in each case. 
The first dataset consists of three distinct communities along a gradient, with no species overlaps (Fig. 3a). It is a rather hypothetical case with totally sharp boundaries. In this case, the central patch cannot be considered a transitional one, since its species composition does not show a transitional character (i.e. there is no species overlap with the neighbouring communities). Total species number was set to 150 , which is close to the real field situations (the average species number along a $200 \mathrm{~m}$ long transect was 169 during field works). Along the artificial gradient, communities have 60, 30 and 60 species, respectively (the central community is shorter and so has fewer species).

The second dataset is more realistic, since the central community is transitional (Fig. $3 b$ ). Although it has its own species (occurring exclusively in the central patch), boundaries towards the neighbouring communities are blurred, with considerable overlaps (that is, the central zone has its own species as well as species from both neighbouring communities). Total species number was again $150(60+30+60)$.

In the third dataset, boundaries are blurred, and the central patch does not have its own species any more (Fig. 3c). Here, total species number is $120(60+60)$, since there are only two communities. Species number is not even along the gradient, but it is higher in the central patch than in the other sections.

In the fourth dataset, the boundaries between the communities are blurred, and the species number is roughly the same along the whole gradient (Fig 3d). Total species number is $120(60+60)$. It should be noted that independence (i.e. distinctness) of the central patch decreases from the first to the fourth dataset.

The fifth dataset contains blurred boundaries (Fig 3e). In this case, the central patch is not transitional, it is, rather, a habitat patch situated in a homogeneous matrix. Here, total species number is only 90 (60 for the matrix and 30 for the small patch).

We hypothesized that real transect data from the Villány Mts would resemble either the second, or the third or the fourth simulated gradient, because a transition is expected near the ridge in the case of field data.

\section{Moving split window analysis}

We used moving split window (MSW) technique (WEBSTER 1978) to study the transitional phenomena on both the artificial and the field data. Squared Euclidean distance (SED) was applied as comparative function, since it is the most commonly used distance metric in MSW studies (JOHNSTON et al. 1992). Significance of the boundaries was tested using the Z-score transformation. Overall mean and standard deviation were computed from 99 randomizations and for the whole transect. Random reference was made with random shift of species. The distribution of each species was shifted a random number of units along the transect. Occurrences that are shifted beyond the end of the transect were wrapped back on to the opposite end (PALMER and VAN DER MAAREL 1995, HoRVÁTH 1998). In order to gain a better understanding of the behaviour of the MSW as well as of the spatial processes occurring near the ridge, we applied three spatial scales by using different window widths: for comparison, Z-scores were averaged over 4-10, 10-20, 30-40 and 50-60 window widths, respectively (since we used $1 \mathrm{~m}^{2}$ quadrats, window width always means meters). Average Z-scores were plotted against window midpoint position, resulting in a Z-score profile. In the profile, vegetation boundaries appear as peaks. MSW profiles for window widths 4-10 
were basically very similar to the profiles for window widths 10-20 along each simulated gradient and field transect. Thus, the results of the smallest window widths were not further evaluated in this study.

The significance test of this statistic is not well developed. Most of the studies do not deal with significance, and mark only the largest peak. In some instances, peaks above expected mean $+2 \mathrm{SD}$ are suggested as significant without further consideration (e.g. CoRNELIUS and REYNOLDS 1991). We intended to reveal a verifiable test, therefore we determined the distribution of z-transformed distance values from randomized data. This is the distribution of expected values for random case. On the basis of the analysis of several hundred simulations (10,000 randomizations in each case), the distribution of Z-scores for randomized data deviated from normal distribution: it was slightly right-skewed. Therefore, confidence limits used for normal distributions were not applicable. Instead, we determined the upper 5\% confidence limit for each simulation, the value of which was less than 1.85 in the most conservative case. We suggested 1.85 be used as the $5 \%$ confidence limit in the case of SED and random shift (other randomizations may result in slightly different confidence limits, especially in the case of the smallest window sizes). Accordingly, peaks above 1.85 were regarded as indicating significant $(\mathrm{p}<0.05)$ boundaries in this study.

The program for the MSW-computations with random reference was written in the statistical language R 2.10.1 (R Development CoRE TeAm 2009). R-source code is given as supplementary material (On-line Supplement Tab. 1).

\section{Results}

\section{Behaviour of the MSW on different artificial datasets}

Analysis of the artificial datasets showed that the MSW method was able to distinguish between transitional zones (second, third and fourth datasets) and zones that did not have a transitional character (first and fifth datasets). In the case of transitional zones, MSW-peaks began to merge with the increase of window width (Figs. 3b, c, d). However, if the central patch was not a transitional one, peaks did not merge even if the largest window widths were applied (Figs. 3a, e). For example, boundaries in the second dataset were as blurred as in the fifth. Nevertheless, while peaks merged in the case of the second dataset (Fig. 3b), peaks did not coalesce in the case of the fifth (Fig. 3e).

In addition, MSW indicated the distinctness of the central zone: the more independent this zone was, the later the peaks merged. In the case of the first artificial dataset (where communities were distinct, without species overlaps), the two peaks remained highly prominent and separate even at the largest window widths (Fig. 3a). In the case of the second artificial dataset, MSW showed two comparatively high peaks at smaller window widths, which began to merge at window widths 30-40. When window widths between 50 and 60 were applied, the two peaks disappeared and a plateau developed (Fig. 3b). This plateau kept its shape even when window width reached 100 (data not shown). In the third case, peaks in the Z-score profile merged at smaller window widths, with no plateau (Fig. 3c). In the case of the fourth dataset, when independence of the central patch was the lowest, double peaks did not appear even at the smallest window widths (Fig. 3d). 
(a)
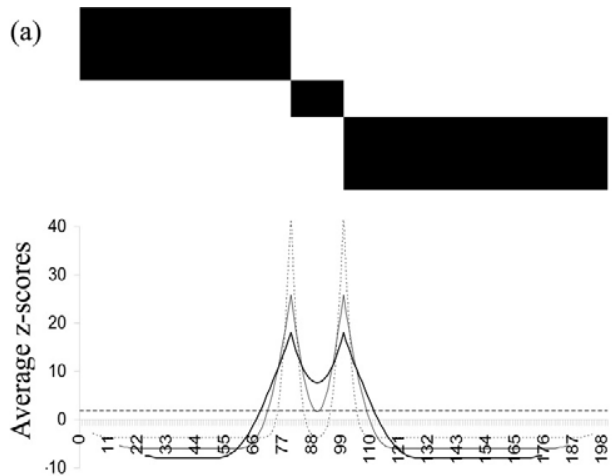

(c)
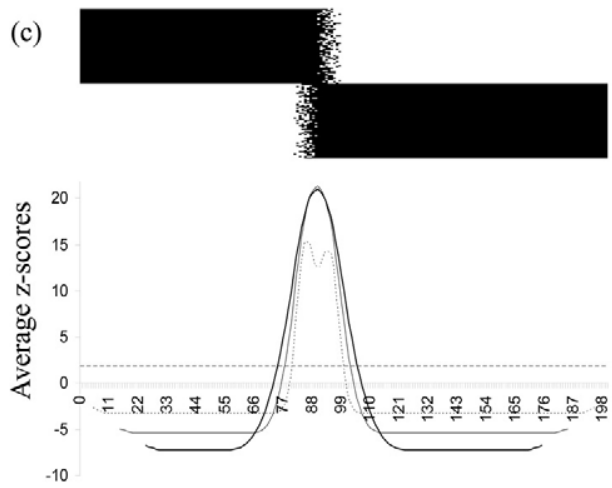

(e)
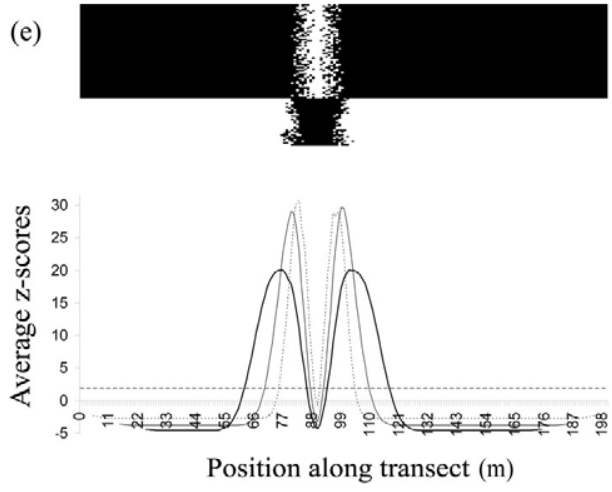

(b)
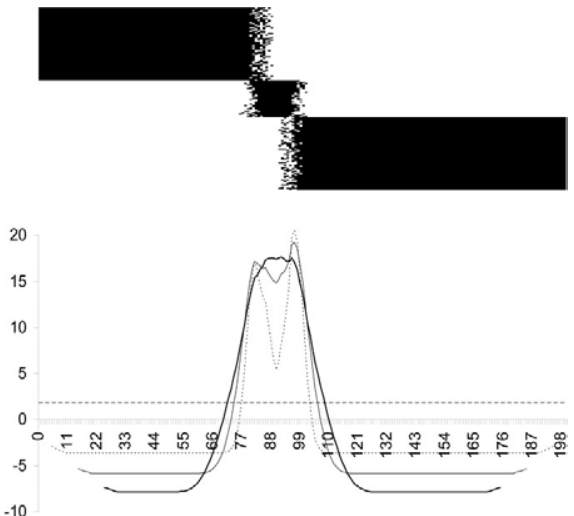

(d)
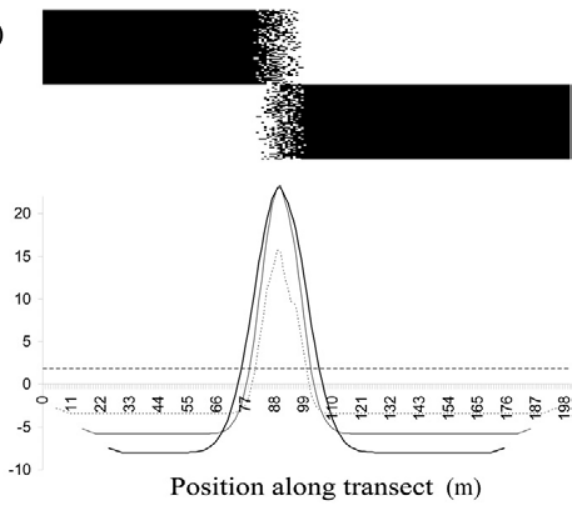

Z-scores were averaged over the following window widths:

$$
\begin{array}{r}
10-20 \\
-30-40 \\
-50-60 \\
\text {-... Critical value }(z=1.85)
\end{array}
$$

Fig. 3. Species distribution patterns in the artificial datasets along a simulated gradient and corresponding Z-score profiles from the MSW. a Three entirely distinct communities with totally sharp boundaries. b Three communities with moderately blurred boundaries. c Communities with blurred boundaries and high species richness in the central zone. d Communities with blurred boundaries and constant species number along the gradient. e Habitat patch in a homogeneous matrix. 
ERDŐs L., ZALATNAI M., BÁTORI Z., KÖRMÖCZI L.

\section{Transitional phenomena between the north-facing and the south-facing slopes}

We found a total of 284 species along the five transects. Species number and most frequent species of the transects are shown in table 1 .

Table 1. Species number and most frequent species of the transects.

\begin{tabular}{|c|c|c|c|}
\hline \multirow[t]{2}{*}{ Transect } & \multirow{2}{*}{$\begin{array}{l}\text { Species } \\
\text { number }\end{array}$} & \multicolumn{2}{|c|}{ Most frequent species } \\
\hline & & Norhthern slope & Southern slope \\
\hline \multirow[t]{5}{*}{$\mathrm{F}$} & 183 & Corydalis cava & Euphorbia cyparissias \\
\hline & & Ranunculus ficaria & Orlaya grandiflora \\
\hline & & Ruscus aculeatus & Festuca dalmatica \\
\hline & & Anemone ranunculoides & Helianthemum ovatum \\
\hline & & Gagea lutea & Teucrium chamaedrys \\
\hline \multirow[t]{5}{*}{ S1 } & 164 & Galanthus nivalis & Orlaya grandiflora \\
\hline & & Corydalis cava & Calepina irregularis \\
\hline & & Helleborus odorus & Melica ciliata \\
\hline & & Anemone ranunculoides & Viola arvensis \\
\hline & & Ranunculus ficaria & Allium sphaerocephalon \\
\hline \multirow[t]{5}{*}{ S2 } & 170 & Veronica hederifolia & Orlaya grandiflora \\
\hline & & Corydalis cava & Geranium rotundifolium \\
\hline & & Lamium purpureum & Lamium amplexicaule \\
\hline & & Anthriscus cerefolium & Melica ciliata \\
\hline & & Acer platanoides & Viola arvensis \\
\hline \multirow[t]{5}{*}{ S3 } & 164 & Veronica hederifolia & Orlaya grandiflora \\
\hline & & Anthriscus cerefolium & Myosotis stricta \\
\hline & & Ranunculus ficaria & Cerastium brachypetalum \\
\hline & & Lamium purpureum & Lamium amplexicaule \\
\hline & & Corydalis cava & Viola arvensis \\
\hline \multirow[t]{5}{*}{$\mathrm{T} 1$} & 166 & Corydalis cava & Euphorbia cyparissias \\
\hline & & Anemone ranunculoides & Orlaya grandiflora \\
\hline & & Ranunculus ficaria & Potentilla arenaria \\
\hline & & Galanthus nivalis & Fraxinus ornus \\
\hline & & Gagea lutea & Teucrium chamaedrys \\
\hline
\end{tabular}

When MSW was applied to field data, three of the five transects resembled our second artificial dataset: transects F, S2 and S3 showed clear double peaks near the ridge, which merged at the largest window widths (Figs. 4a, c, d). The area between the two peaks in the Z-score profile coincided with the area occupied by the grassland community Festuco rupicolae-Arrhenatheretum in the real space (near the mountain ridge). In the case of transect S2, a wider and internally inhomogeneous transitional zone can be presumed when the largest window widths are considered (Fig. 4c). This zone contains parts of a top-forest and of a shrubforest community. 


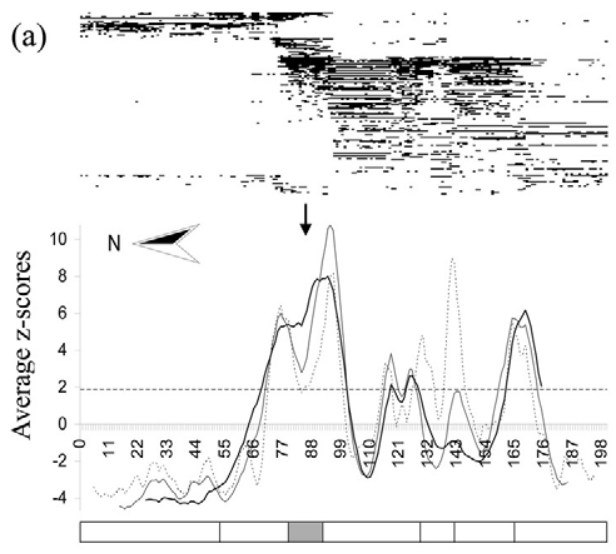

(b)
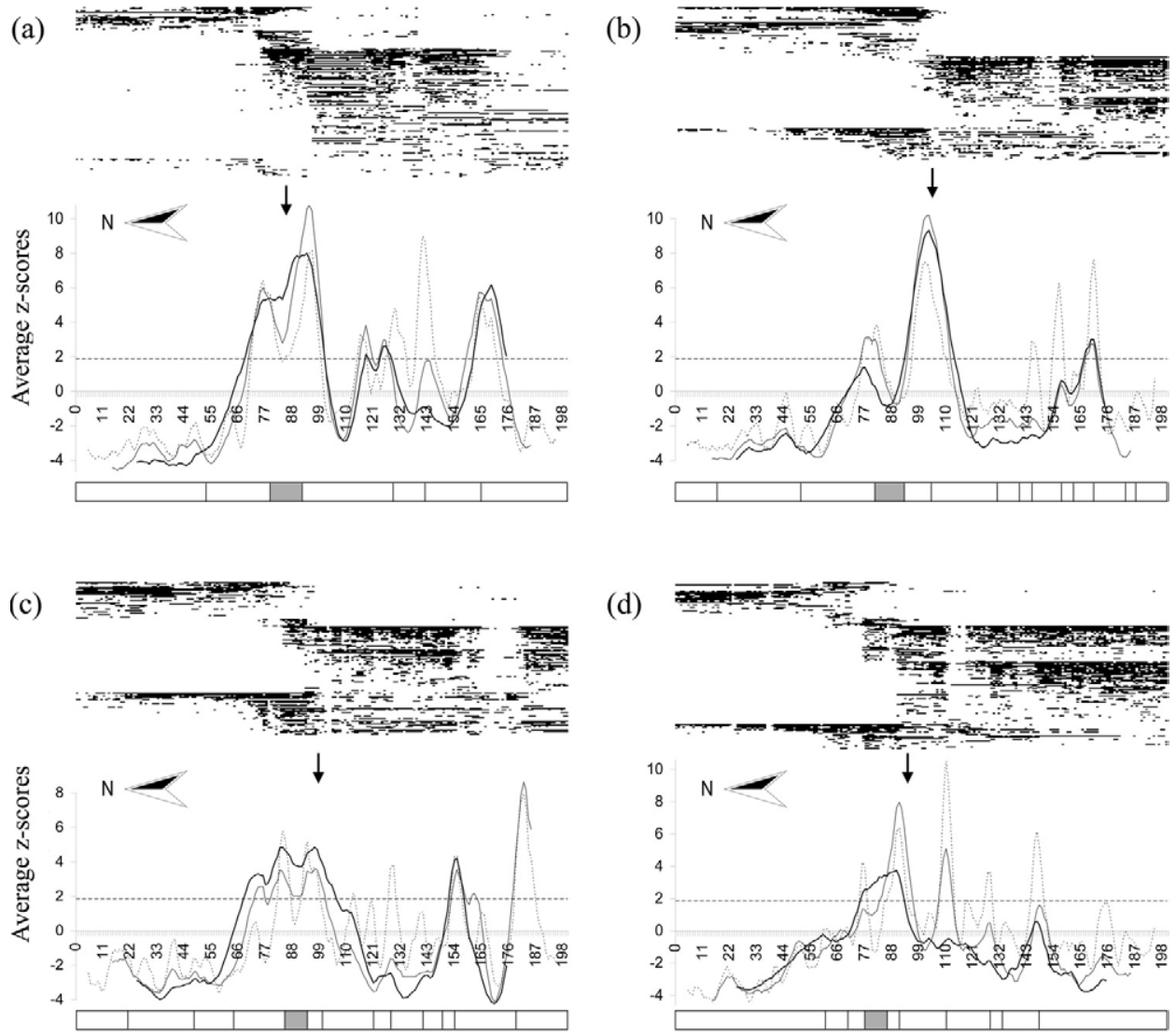

(d)
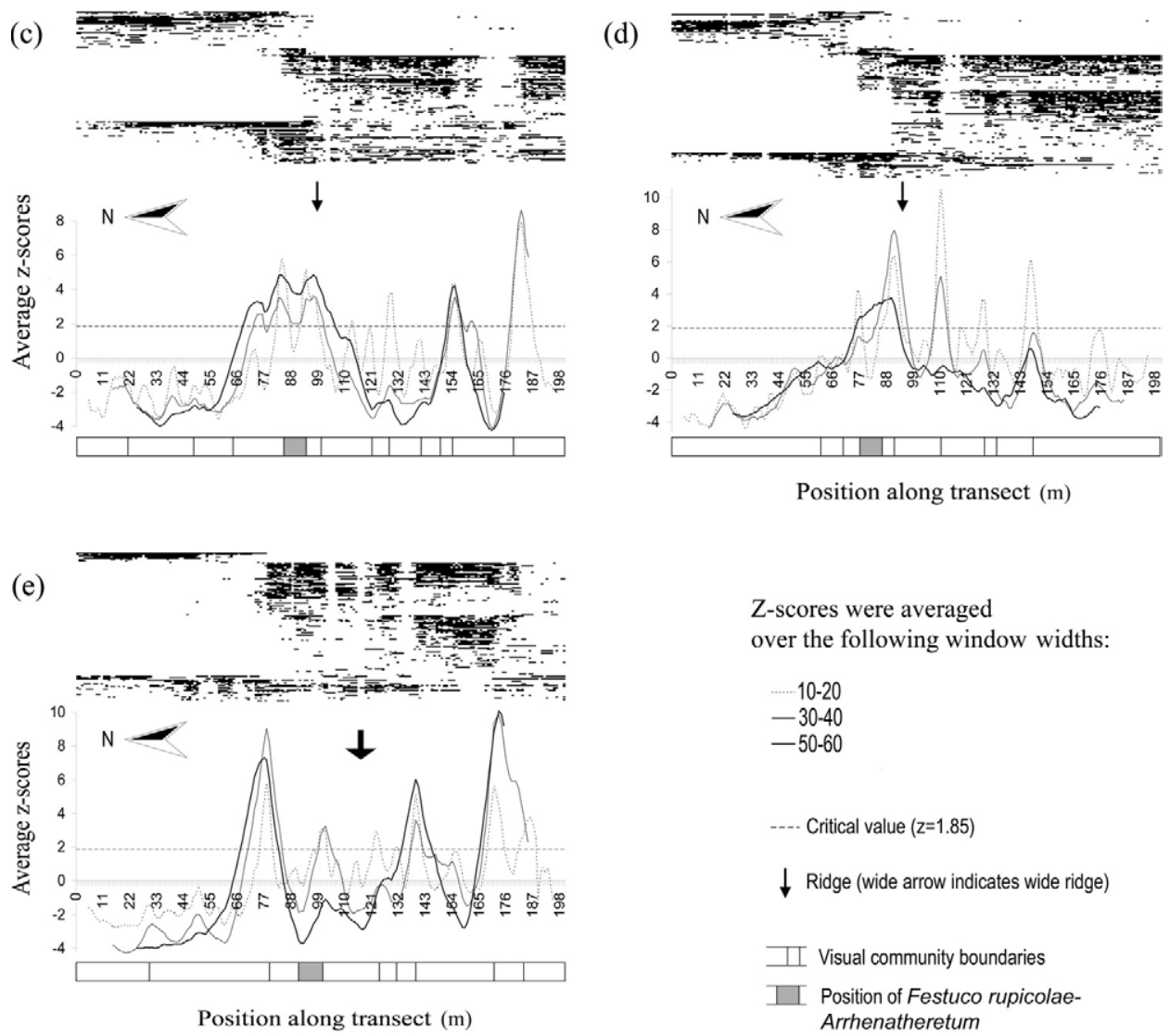

Z-scores were averaged over the following window widths:

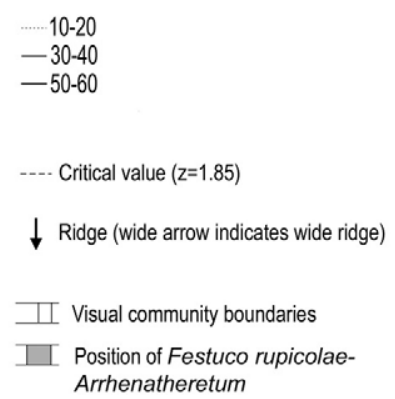

Fig. 4. Species distribution patterns along the transects from field studies and corresponding Z-score profiles from the MSW. In the distribution patterns, only species occurring in at least five plots are displayed. a Transect F. b Transect S1. c Transect S2. d Transect S3. e Transect T. 
In the case of transect S1, double peaks appeared near the ridge: one of them was very high, whereas the other one was comparatively low (Fig. 4b). Peaks did not merge at greater window widths. Instead, the most prominent peak indicates a rather abrupt transition on the mountain ridge. This transition occurs between a small north-exposed shrubforest patch and a south-exposed rock sward.

As for transect T, a conspicuous peak emerged north of the ridge (Fig. 4e). This indicates the boundary between a top-forest community and a more open, xeric shrubforest patch.

\section{Discussion}

Simulated communities can be used to gain a better understanding of the properties of MSW, which in turn helps to interpret results originating from field data (BRUNT and CONLEY 1990). Our simulations showed that using MSW, one can distinguish between transitional zones and zones that do not represent real transitions. If a zone does not have a transitional character, peaks in the Z-score profile will not merge even at the greatest window-widths (this was illustrated with the first and the fifth datasets) (Figs. 3a, e). In contrast, if a patch is transitional between two communities along a gradient, peaks will merge at greater window widths. It was observed by KÖRMÖCZI (2005) that MSW produces different results when a transitional community is being studied and when the community in the middle is rather a patch in a homogeneous matrix. However, KÖRMÖCZI (2005) used only two simulated gradients. Our results reinforce his findings and suggest that the observed phenomenon is general.

Influence of the distinctness of a community on the coalescence of the MSW peaks has not been studied formerly (cf. BRUNT and CONLEY 1990, KÖRMÖCZI 2005). We found that distinctness (independence) of the transitional zone determines the coalescence of the peaks of the profile. If the transitional unit is relatively independent (e.g. it has its own species occurring only in the transitional community), the peaks will merge only at larger window widths, and a plateau forms (Fig. 3b). This plateau does not disappear, but it keeps its shape even at much greater window widths. If independence of the transitional unit is lower, the peaks merge at smaller window widths forming a single peak, and no plateau appears (Fig. 3c). If distinctness is even lower, double peaks will not appear even at the smallest window widths (Fig. 3d). This finding contradicts KöRMÖCZI (2005), who stated that coalescence of the peaks depends on the width of the transitional zone. For example, in the case of the third and fourth artificial datasets, width of the transition was exactly the same (20 plots). Nevertheless, peaks did not merge at the same window widths in these two cases (Figs. 3c, d).

Analyses of the field data showed that in three of the five transects (F, S2, S3), the transition between the mesic north-exposed slope and the xeric south-exposed slope occurs in the grassland community Festuco rupicolae-Arrhenatheretum. Our study also demonstrated that this vegetation unit can be conceived as a boundary or as a zone in its own right, with its own two boundaries. Interpretation may solely depend on the resolution of the study. In the case of transects F, S2 and S3, at finer resolutions (at smaller window widths) the transitional grassland unit north of the ridge has its own two boundaries, indicated by the peaks in the Z-score profile (Figs. 4a, c, d). However, at the greatest window widths (i.e. at a coarse resolution), peaks merge. This shows that this vegetation unit may be regarded as a boundary between the mesic northern slope and the xeric southern slope. 
Similar grasslands have been studied in South Hungary (near the Villány Mts) by LENGYEL et al. (2012). They examined mesic meadows of the Arrhenatheretalia order and some related syntaxonomic units. Interestingly, they found some grasslands that represented transitional states between mesic (Arrhenatheretalia) and semi-dry (Brometalia erecti) meadows, with the occurrence of both mesic and xeric species. Species composition of those grasslands seems to resemble the community Festuco rupicolae-Arrhenatheretum (e.g. the dominance of Arrhenatherum elatius, Festuca rupicola and Teucrium chamaedrys, high constancy of Dianthus giganteiformis and Sanguisorba minor, and a number of other common species). However, there is a fundamental difference: the position of Festuco rupicolae-Arrhenatheretum is near the ridges, while the similar relevés of LENGYEL et al. (2012) are not situated near mountain ridges (CSIKY personal communication). In the case of the Villány Mts, the transitional character of Festuco rupicolae-Arrhenatheretum communities can be explained by their being located near mountain ridges. Consequently, they form a transition between the community complexes of differently oriented slopes. In the case of the relevés of LENGYEL et al. (2012), ecological indicator values suggest that factors such as temperature and light regimes are higher than in mesic but lower than in semi-dry grasslands, while the reverse is true for moisture and nutrient availability. Since these stands are situated either in lowlands or on south-facing slopes, but never near ridges, overshadowing by neighbouring forest stands could be responsible for their transitional environmental conditions (the grasslands themselves have formed in the place of cleared forests, which probably also influences their special state).

The transitional grassland community Festuco rupicolae-Arrhenatheretum has already aroused our interest, and we examined it using classical coenological methods (ERDŐs et al. 2010). The present study reinforces the idea that it is a distinct vegetation unit, as it is bordered by relatively sharp boundaries (high peaks in the Z-score profile at small window widths). On the other hand, it has a strong transitional character, and represents a boundary zone between the northern and the southern slopes (merging peaks at greater window widths). However, we have to note that, concerning other areas in the region, stands of this community do not necessarily form boundary zones between community complexes of differently exposed slopes.

Similar transitional zones were identified using the MSW method by ZALATNAI and KÖRMÖCZI (2004) in alkaline grasslands of Hungary. Transitional zones were visually detected during field studies. These were examined in detail using the MSW method. Smaller window widths showed double peaks indicating the boundaries of the transitional zones, whereas double peaks merged at larger window widths, emphasizing that the zone represents an intermediate type between the two neighbouring units.

The results were quite different in transects $\mathrm{S} 1$ and $\mathrm{T}$. In the case of transect $\mathrm{S} 1$, the transitional character of the community Festuco rupicolae-Arrhenatheretum is less prominent, as peaks do not merge (Fig. 4b). The grassland resembles the north-exposed communities, probably because this is the steepest north-facing slope of the five transects $\left(30^{\circ}\right)$, and the grassland is partly overshadowed by the neighbouring trees. These factors probably entail cooler and more humid conditions, enabling the establishment of a larger number of species typical of mesic forests.

In the case of transect T, a conspicuous boundary is situated north of the ridge (Fig. 4e). In this case, the grassland community north of the ridge does not represent a transitional state, but it resembles the xeric communities of the southern slope. This is probably due to 
the fact that slope inclination at this section is small $\left(8^{\circ}\right)$. Moreover, soil is shallow and stony, resembling conditions of the south-facing slope.

Transitions between steep southern and northern slopes have been studied in the Transdanubian Mountain Ranges (KeVEY and BorHIDi 2002) and in the Mecsek Mts (KeVEY and BoRHIDI 1998, 2005). It was found that transitions occur within ecotonal-type forests, where mesic and xeric species co-occur. In contrast, in the Villány Mts, transitions seem to occur mostly in the grasslands north of the ridges. This pattern was found in three of the five transects under scrutiny $(\mathrm{F}, \mathrm{S} 2, \mathrm{~S} 3)$. In the remaining two transects $(\mathrm{S} 1, \mathrm{~T})$, transition was rather abrupt, occurring either on the mountain ridge, or at the edge of the mesic forests.

It was recognized in vegetation ecology that a vegetation unit of transitional character can be considered a boundary or a zone in its own right, depending on the spatial resolution (cf. ARMAND 1992, KolASA and ZALEWSKI 1995). Thus, multi-scale approaches are necessary to scrutinize such transitional units. Our analyses suggest that MSW provides an appropriate tool for these studies. It can identify spatial resolutions at which the transitional vegetation unit should be regarded as a boundary, and resolutions at which it is rather a unit in its own right.

Our study serves as an example to show that MSW can effectively support classical coenological methods: if MSW shows that the vegetation unit under study has significant boundaries with the neighbouring communities, it may be treated as a separate unit at the given resolution.

\section{Acknowledgements}

The authors would like to thank the Inspectorate for Environment, Nature and Water for allowing us to carry out these studies in the strictly protected nature reserves of the Villány Mountains. We are also thankful to János Csiky, Tamás Morschhauser and the Department of Plant Taxonomy and Geobotany of the University of Pécs for the technical support. This work was supported by the Project TÁMOP-4.2.1/B-09/1/KONV-2010-0005 (»Kutatóegyetemi Kiválósági Központ létrehozása a Szegedi Tudományegyetemen«).

\section{References}

Ambrózy, P., KozMA, F., 1990: Villány Mountains: Climate (In Hungarian). In: MAROsi, S., Somogyi, S. (eds.), Cadaster of the basic landscape units of Hungary II., 576-577. MTA Földrajztudományi Kutató Intézet, Budapest.

ARMAND, A. D., 1992: Sharp and gradual mountain timberlines as a result of species interactions. In: HANSEN, A. J., DI CASTRI, F. (eds.), Landscape boundaries: consequences for biotic diversity and ecological flows, 360-378. Springer-Verlag, New York.

ARMESTO, J. J., MARTíNEZ, J. A., 1978: Relations between vegetation structure and slope aspect in the Mediterranean region of Chile. Journal of Ecology 66, 881-889.

Austin, M. P., 2005: Vegetation and environment: discontinuities and continuities. In: VAN Der MAArel, E. (ed.), Vegetation ecology, 52-84. Blackwell, Oxford.

BÁtori, Z., GAllé, R., ERdös, L., KÖRMÖCZI, L., 2011: Ecological conditions, flora and vegetation of a large doline in the Mecsek Mountains (South Hungary). Acta Botanica Croatica 70, 147-155. 
BRunT, J. W., CONLEY, W., 1990: Behavior of a multivariate algorithm for ecological edge detection. Ecological Modelling 49, 179-203.

Cadenasso, M. L., Pickett, S. T. A., Weathers, K. C., Jones, C. G., 2003: A framework for a theory of ecological boundaries. BioScience 53, 750-758.

Choesin, D., Boerner, R. E. J., 2002: Vegetation boundary detection: A comparison of two approaches applied to field data. Plant Ecology 158, 85-96.

Cornelius, J. M., Reynolds, J. F., 1991: On determining the statistical significance of discontinuities within ordered ecological data. Ecology 72, 2057-2070.

DÉNES, A., 1995: Karst shrubforest of the Mecsek and the Villány Mts (In Hungarian). A Janus Pannonius Múzeum Évkönyve 39, 5-31.

DÉNES, A., 2000: History of research on flora and vegetation in the Villány Mts, a summary of results, with special regard to the occurrence of rare and protected species (In Hungarian). Dunántúli Dolgozatok 10, 47-77.

ERdős, L., DÉNES, A., MorschHAUSER, T., 2010: Description and characterization of a new rock sward association in the Villány Mountains (Festuco rupicolae-Arrhenatheretum Erdős et Morschhauser ass. nova.). Acta Botanica Hungarica 52, 315-330.

ERdős, L., GAllé, R., BÁTORI, Z., PAPP, M., KÖRMÖCZI, L., 2011a: Properties of shrubforest edges: a case study from South Hungary. Central European Journal of Biology 6, 639-658.

ERdős, L., Méri, Á., BÁtori, Z., GAllé, R., KöRmÖCZI, L., 2012: North-south facing vegetation gradients in the Villány Mts: a case study on the population and the community level. Pakistan Journal of Botany 44, 927-932.

Erdős, L., Zalatnai, M., Morschhauser, T., BÁtori, Z., KöRmöczi, L., 2011b: On the terms related to spatial ecological gradients and boundaries. Acta Biologica Szegediensis 55, 279-287.

FODOR, I., 1977: Villány Mountains: air temperature (In Hungarian). In: LovÁsz, Gy. (ed.), Geography of Baranya county, 118-135. Baranya Megyei Levéltár, Pécs.

Gosz, J. R., 1993: Ecotone hierarchies. Ecological Applications 3, 369-376.

Hennenberg, K. J., Goetze, D., Kouamé, L., Orthmann, B., Porembski, S., 2005: Border and ecotone detection by vegetation composition along forest-savanna transects in Ivory Coast. Journal of Vegetation Science 16, 301-310.

HoRvÁTH, A., 1998: INFOTHEM program: new possibilities of spatial series analysis based on information theory methods. Tiscia 31, 71-84.

HoRvÁt, A. O., 1968: Die Hainbuchen-Eichenwälder der Mecsek-Gegend in Südungarn. Feddes Repertorium 77, 163-176.

Hufkens, K., Scheunders, P., Ceulemans, R., 2009: Ecotones in vegetation ecology: methodologies and definitions revisited. Ecological Research 24, 977-986.

JAGOMÄGI, J., KÜLVIK, M., MANDER, Ü., JACUCHNO, V., 1988: The structural-functional role of ecotones in the landscape. Ekologia ČSSR 7, 81-94.

JAKUCS, P., 1972: Dynamische Verbindung der Wälder und Rasen. Akadémiai Kiadó, Budapest. 
Johnston, C. A., Pastor, J., Pinay, G., 1992: Quantitative methods for studying landscape boundaries. In: HANSEN, A. J., DI CASTRI, F. (eds.), Landscape boundaries: Consequences for biotic diversity and ecological flows, 107-125. Springer Verlag, New York.

Kent, M., Gill, W. J., Weaver, R. E., Armitage, R. P., 1997: Landscape and plant community boundaries in biogeography. Progress in Physical Geography 21, 315-353.

Kevey, B., BorhIDI, A., 1998: Top-forest (Aconito anthorae-Fraxinetum orni) a special ecotonal case in the phytosociological system (Mecsek Mts, South Hungary). Acta Botanica Hungarica 41, 27-121.

Kevey, B., BorhIDI, A., 2002: Top-forests (Veratro nigri-Fraxinetum orni) of the Bakony Mountains. Acta Botanica Hungarica 44, 85-115.

Kevey, B., BorHIDI, A., 2005: The acidophilous forests of the Mecsek and their relationship with the Balkan-Pannonian acidophilous forests. Acta Botanica Hungarica 47, 273-368.

KolasA, J., ZalewsKi, M., 1995: Notes on ecotone attributes and functions. Hydrobiologia $303,1-7$.

KÖRMÖCZI, L., 2005: On the sensitivity and significance test of vegetation boundary detection. Community Ecology 6, 75-81.

KrÖGER, R., KhOMO, L. M., Levick, S., Rogers, K. H., 2009: Moving window analysis and riparian boundary delineation on the Northern Plains of Kruger National park, South Africa. Acta Oecologica 35, 573-580.

Kutiel, P., LAVEe, H., 1999: Effect of slope aspect on soil and vegetation properties along an aridity transect. Israel Journal of Plant Sciences 47, 169-178.

LAurance, W. F., Didham, R. K., Power, M. E., 2001: Ecological boundaries: a search for synthesis. Trends in Ecology and Evolution 16, 70-71.

Lengyel, A., Purger, D., CsiKy, J., 2012: Classification of mesic grasslands and their transitions of South Transdanubia (Hungary). Acta Botanica Croatica 71, 31-50.

LovÁsz, Gy., 1977: Geomorphological districts (In Hungarian). In: LovÁsz, Gy. (ed.), Geography of Baranya county, 43-93. Baranya Megyei Levéltár, Pécs.

Ludwig, J. A., CoRnelius, J. M., 1987: Locating discontinuities along ecological gradients. Ecology 68, 448-450.

Magyari, E. K., Chapman, J. C., Passmore, D. G., Allen, J. R. M., Huntley, J. P., HuntLEY, B., 2010: Holocene persistence of wooded steppe in the Great Hungarian Plain. Journal of Biogeography 37, 915-935.

Muños-Reinoso, J. C., 2001: Sequential pattern in the stabilized dunes of Doòana Biological Reserve (SW Spain). Journal of Coastal Research 17, 90-94.

PALMER, M. W., VAN DER MAAREL, E., 1995: Variance in species richness, species association, and niche limitation. Oikos 73, 203-213.

Peters, D. P. C., Gosz, J. R., Pockman, W. T., Small, E. E., Parmenter, R. R., Collins, S. L., Muldavin, E., 2006: Integrating patch and boundary dynamics to understand and predict biotic transitions at multiple scales. Landscape Ecology 21, 19-33.

Pócs, T., 2000: Plant biogeography (In Hungarian). In: Hortobágyi, T., Simon, T. (eds.), Plant biogeogrphy, phytocoenology and ecology, 25-166. Nemzeti Tankönyvkiadó, Budapest. 
R Development Core Team, 2009: R: A Language and Environment for Statistical Computing. R Foundation for Statistical Computing, Vienna. Retrieved September 25, 2011 from http://www.R-project.org

SIMON, T., 1964: Entdeckung und Zönologie der Festuca dalmatica (HACK.) RICHT. in Ungarn und ihr statistischer Vergleich mit ssp. pseudodalmatica (KRAJ.) SOÓ. Annales Universitatis Budapestiensis Sectio Biologica 7, 143-156.

Sternberg, M., Shoshany, M., 2001: Influence of slope aspect on Mediterranean woody formations: Comparison of a semiarid and an arid site in Israel. Ecological Research 16, 335-345.

SzABÓ, I., 1990: Investigations on the flora and vegetation of Keszthely hills (Hungary) with special regard to their southern elements. In: SzABó, I. (ed.), Illyrische Einstrahlungen im Ostalpin-Dinarischen Raum, 79-88. Pannon Agraruniversität, Keszthely.

ToRmA, A., KöRmÖCZI, L., 2009: The influence of habitat heterogeneity on the fine-scale pattern of an Heteroptera assemblage in a sand grassland. Community Ecology 10, $75-80$.

VAN DER MAAREL, E., 1976: On the establishment of plant community boundaries. Berichte der Deutschen Botanischen Gesellschaft 89, 415-443.

Webster, R., 1978: Optimally partitioning soil transects. Journal of Soil Science 29, 388-402.

Westhoff, V., 1974: Stufen und Formen von Vegetationsgrenzen und ihre methodische Annäherung. In: TüXEN, R. (ed.), Tatsachen und Probleme der Grenzen in der Vegetation, 45-64. Verlag von J. Cramer, Lehre.

WHITTAKER, R. H., 1967: Gradient analysis of vegetation. Biological Reviews 42, 207-264.

Wiens, J. A., CRAwFord, C. S., Gosz, J. R., 1985: Boundary dynamics: a conceptual framework for studying landscape ecosystems. Oikos 45, 421-427.

WIENS, J. A., 1992: Ecological flows across landscape boundaries: a conceptual overview. In: HANSEN, A. J., DI CASTRI, F. (eds.), Landscape boundaries: consequences for biotic diversity and ecological flows, 217-235. Springer-Verlag, New York.

ZalATNAI, M., KÖRMÖCZI, L., 2004: Fine-scale pattern of the boundary zones in alkaline grassland communities. Community Ecology 5, 235-246. 